\title{
Bone Leiomyosarcoma
}

National Cancer Institute

\section{Source}

National Cancer Institute. Bone Leiomyosarcoma. NCI Thesaurus. Code C7154.

A rare aggressive malignant smooth muscle neoplasm, arising from the bone. It is characterized by a proliferation of neoplastic spindle cells. 